\title{
Identification of multi-drug resistance gene (MDR1) in equine ileum
}

\author{
Identificação do gene de resistência múltipla aos fármacos no íleo de eqüiinos
}

\author{
Cláudio Corrêa Natalini ${ }^{1}$ Renata Lehn Linardi ${ }^{1}$
}

\begin{abstract}
$P$-glycoprotein $(P-g p)$ is a membrane transporter ABSTRACT encoded in the Multi-drug Resistance (MDR1) gene expressed in several normal tissues and over expressed in tumor cells. $P$ gp was already identified in different species but not yet in equine. MDRl gene and P-gp are able to interfere with bioavailability and disposition of several drugs, altering pharmacokinetic and pharmacodinamic of drugs. The presence of the MDRI and P-gp in the central nervous system blocks the entry of certain drugs in this tissue and reduces drug absorption and enhances drug elimination when P-gp and MDR1 are presented in the gastrointestinal tract. This study showed that the MDRl gene is present in equine ileum. Future studies on the impact of the P-glycoprotein encoded gene MDRI on drugs pharmacologic effects in horses are granted.
\end{abstract}

Key words: molecular biology, opioids, equine, gene, MDR1, $A B C B 1$.

\section{RESUMO}

P-glicoproteína (P-gp) é uma membrana de transporte expressa pelo gene de resistência múltipla (MDR1), presente em diversos tecidos e normais e células tumorais. Embora o gene MDR1 e a P-gp já tenham sido identificados em diferentes espécies, ainda não se têm informações com relação à especie equina. $O$ gene $M D R 1$ e a $P$-gp são capazes de interferir com a bioviabilidade e a disposição de diversos fármacos, alterando a farmacocinética e a farmacodinâmica dos mesmos. A presença do gene MDR1 e da P-gp no sistema nervoso central impede a entrada de certos fármacos neste tecido e, no trato gastrointestinal, eles reduzem a absorção de fármacos e aumentam sua eliminação. Neste estudo, comprovou-se pela primeira vez, a presença do gene MDRI no íleo de eqüinos. Sugere-se que estudos futuros sejam realizados para a determinação do impacto da presença da $P$ glicoproteína nos efeitos de diversos fármacos em eqüinos.

Palavras-chave: biologia molecular, opióides, eqüino, gene, MDR1, ABCB1.

Traditionally, drug disposition (absorption, distribution, metabolism and excretion) has been considered a passive process. Major factors that affect drug absorption from the intestinal lumen pertain to physicochemical properties of the drug (e.g. pKa, molecular weight, lipophilicity and solubility) and biological factors (e.g. gastric and intestinal transit time, luminal $\mathrm{pH}$ and mucosal blood flow) (LIN et al., 2003). In addition the ability of drugs to cross the bloodbrain barrier and blood-placenta barrier has long been recognized to be predicated by molecular weight, degree of ionization, protein binding, and lipid solubility (WANDEL et al., 2002). In 1976, JULIANO \& LING identified in mammalian tumor cells resistant to multi anticancer agents, a large (140-170kDa) plasma membrane protein which was called "permeability glycoprotein" or "P-glycoprotein". P-glycoprotein is an energy-dependent efflux pump able to export numerous substrates from its intracellular domain to its extracellular domain (FROMM, 2004) and it is

1Departament of Veterinary Clinical Sciences, Louisiana State University, Baton Rouge, LA 70803, USA. Email: cnatalini@vetmed.lsu.edu Author correspondence. 
expressed in normal tissues (intestinal epithelium cells, hepatic cells, renal tubule cells and endothelial cells of the placenta and brain blood-tissue-barriers). The Pglycoprotein is coded by the multidrug resistance gene (MDR-1 gene) which express at a relatively high level in human digestive tracts (SCHINKEL et al., 1996). The expression of the P-glycoprotein results in reduced drug absorption from gastrointestinal tract once the drug has reached the blood circulation. P-glycoprotein enhances the drug elimination into the bile and urine as a result of its expression in the canalicular membrane of hepatocytes and in the luminal membrane of proximal tubule cells in the kidneys. In addition P-glycoprotein acts by blocking the entry of certain drugs into certain sensitive tissues such as the central nervous system, fetal circulation, lymphocytes and testis (FROMM, 2004).

The objectives of this study were to identify the presence of the MDR1 gene in equine species and obtain the horse MDR1 gene sequence.

This study was conducted at the Louisiana State University (LSU) School of Veterinary Medicine (SVM), in the Biomed Division. The protocol was approved by the Institutional Animal Care and Use Committee, license number 72-3 protocol number 04-106.

Samples of the middle part of the equine ileum were collected shortly post-mortem from horses subjected to euthanasia due to medical recommendation with no previous history of GI tract disease. After rinsed, $0.25 \mathrm{~g}$ of each sample was frozen in polyethylene micro tubes and stored at $-80^{\circ} \mathrm{C}$.

Total RNA was isolated using a TRI REAGENT $^{\circledR}$ LS (Molecular Research Center, Inc.) per the manufacturer's protocol. The DNAase treatment and the second time of RNA extraction procedure were conducted to avoid contamination of DNA.

The concentration of RNA was determined using a spectrophotometer, using a 1:50 dilution solution, mixing $12 \mu \mathrm{l}$ of RNA solution in $588 \mu \mathrm{l}$ of sterile water.

RNA was transformed in cDNA using of First-Strand Reaction Mix Beads following Ready To Go® instructions (Molecular Biology Reagents). This cDNA was employed as a template for polymerization using a Polymerase Chain Reaction (PCR). The genespecific PCR primers were previously designed using Primer Express software (Applied Biosystems) from rabbit sequence obtained in a Gene Bank.

PCR reactions were carried out using a GeneAmp PCR System 9600 (Perkin Elmer) the set in ideal conditions $\left(94^{\circ} \mathrm{C}-30\right.$ seconds, $62^{\circ} \mathrm{C}-30$ seconds, $72^{\circ} \mathrm{C}-1$ minute and 33 cycles).
Templates were mixed with Desoxyribonucleotide triphosphate dNTP, buffer, DNA polymerase (taq enzyme), Forward and Reverse primers previously designed by Primer Express TM 1.5 (Applied Biosystem) based on the rabbit sequence and sterile water to bring the solution to a volume of $100 \mu \mathrm{l}$.

The PCR products were analyzed by $1 \%$ agarose gel electrophoresis, prepared with Gene Pure LEAgarose ${ }^{\circledR}$ (Bio Express, UT), 1xTris Acetate Buffer (TAE) and $2 \mu \mathrm{l}$ of bromide. The gel was analyzed in FluorChem ${ }^{\mathrm{TM}} 880$ to verify the presence of single and discreet bands which correspond to primers match in the DNA template (figure 1).

To recovery pure DNA fragments from agarose gel, Zymoclean ${ }^{\mathrm{TM}}$ Gel DNA Recovery Kit's instructions were followed to give more efficiency to ligation and sequencing reading. The PCR product was cloned into pcDNA 3.1/V5-His-TOPO® plasmid vector and transformed into $\boldsymbol{E}$. coli cells. The colonies were selected and analyzed and the plasmid DNA was extracted. Plasmid DNA was purified or removed using QUIAGEN plasmid purification protocol (Qiawell@ Plasmid Purification System) and the concentration of DNA was determined to be sequence.

The sequence obtained matched in $83 \%$ with rabbit sequence. The results of this study showed that the MDR1 gene is present in equine ileum.

Together with xenobiotics-metabolizing enzymes, constitutive P-glycoprotein expression is believed to be an important protective mechanism against potentially toxic xenobiotics (FROMM, 2004). Also P-glycoprotein is capable of actively pumping a variety of drugs out of the central nervous system and is an important component of the blood-brain barrier (CORDON-CARDO et al., 1989). P-glycoprotein has been hypothesized to modulate intestinal drug metabolism by increasing the exposure of drug to intracellular enzyme cytochrome P4503A4 (CYP3A4) through repeated cycles of drug absorption and efflux (CUMMINS et al., 2003). After oral administration of methadone in mice, absorption from the gastrointestinal tract is modulated by the MDR1 gene and the P-glycoprotein (MUKHOPADHYAY et al., 1988). There are no reports on the importance of the Pglycoprotein encoded MDR1 gene in regard to intestinal absorption of drugs in horses. The authors concluded that once the presence of this gene in the equine intestine was proved, futures studies should be done to investigate the impact of the MDR1 gene on drug pharmacology in horses. 


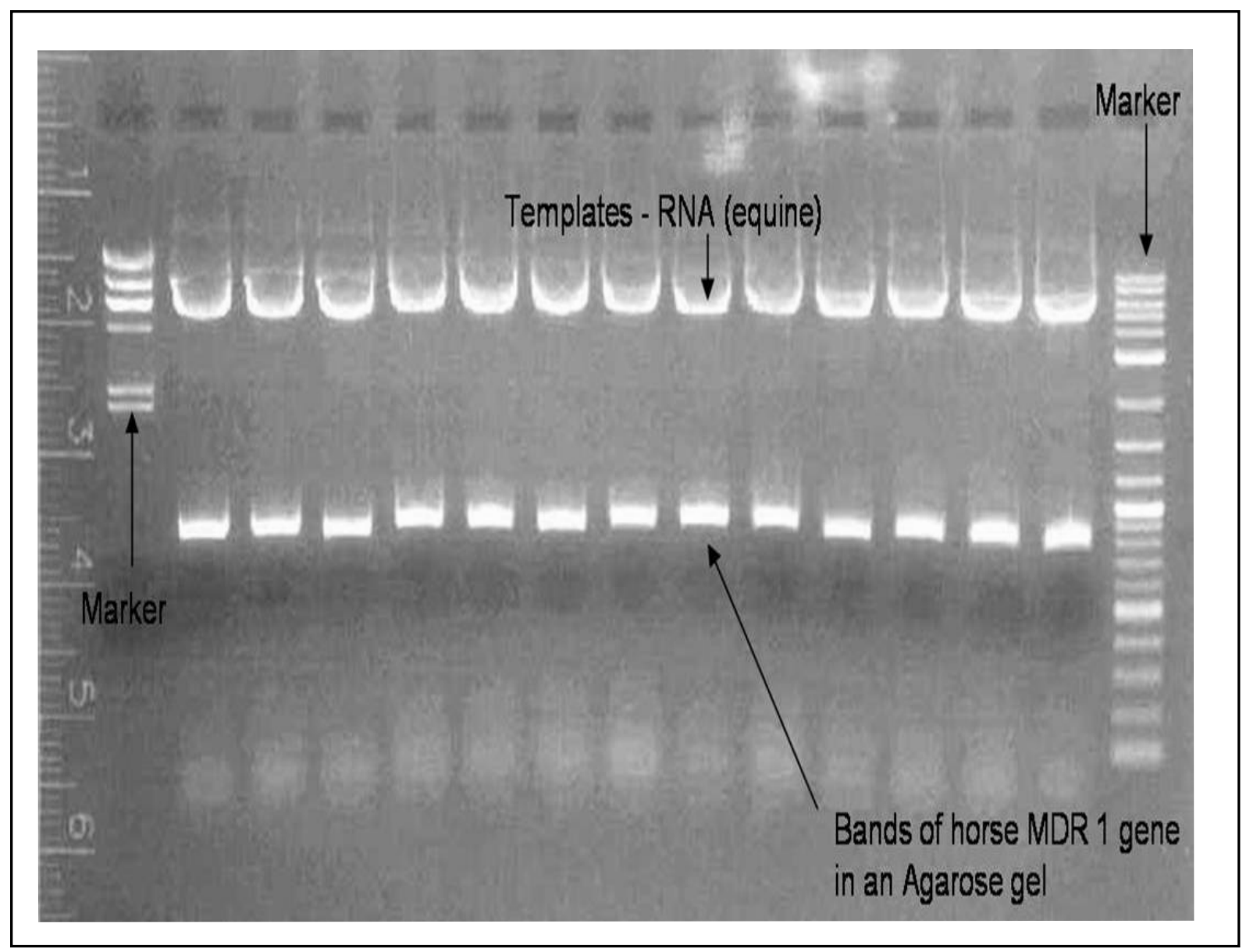

Figure 1 - Multidrug resistance gene (MDR1) DNA (PCR product, white arrow) in equine ileum (agarose gel treated with RNAase).

\section{REFERENCES}

CORDON-CARDO, C. et al. Multidrug-resistance gene (Pglycoprotein) is expressed by endothelial cells at blood-brain barrier sites. Proceedings of the National Academy of Sciences of the United States of America, Washington, v.86, n.2, p.695-698, 1989.

CUMMINS, C.L. et al. In vivo modulation of intestinal CYP3A metabolism by P-glycoprotein: studies using the rat single-pass intestinal perfusion model. Journal of Pharmacology and Experimental Therapeutics, Baltimore, v.305, n.1, p.306314, 2003.

FROMM, M.F. Importance of P-glycoprotein at blood-tissue barriers. Trends in Pharmacoligal Sciences, Amsterdam, v. 25, n. 8, p. $423-429,2004$.

JULIANO, R.L.; LING, V. A suface glycoprotein modulating drug permeability in Chinese hamster ovary cell mutants.
Biochimica et Biophysica Acta, Amsterdam, v.455, p.152162, 1976.

LIN, J.H. et al. Role of P-glycoprotein in pharmacokinetics: clinical implications. Clinical Pharmacokinetics, New York, v.42, p.59-98, 2003.

MUKHOPADHYAY, T. et al. Expression of the MDR (Pglycoprotein) gene in Chinese hamster digestive tracts. Journal of the National Cancer Institute, Bethesda, v.80, n.4, p.269$275,1988$.

SCHINKEL, A.H. et al. P-glycoprotein in the blood-brain barrier of mice influences the brain penetration and pharmacological activity of many drugs. Journal of Clinical Investigation, New Haven, v.97, n.11, p.2517-2524, 1996.

WANDEL, C. et al. Interaction of morphine, fentanyl, sufentanil, alfentanil, and loperamide with the efflux drug transporter P-glycoprotein. Anesthesiology, Philadelphia, v.96, n.4, p. 913-920, 2002. 